nucleus, which contains DNA, invariably dividing to produce two male gametic nuclei, both of which also contain DNA. Here it is interesting to note that Coulter and Chamberlain ${ }^{8}$ as far back as 1903 were able to differentiate between the female and mole nuclei in the embryo sac on the basis of staining reactions without, however, realizing its significance.

From these observations we may further suggest that the division of the fertilized egg and central fusion nuclei is initiated by the re-introduction of DNA by the male nuclei. A similar explanation would also apply for the normal development of sea urchin eggs, where again only the sperm nucleus appears to contain deoxyribonucleic acid.

This view that DNA synthesis provides a regulating mechanism for nuclear activity has wider implications, of which the following may be mentioned.

(a) The reference by Darlington and Mather' to the apparent development of vetch plants from lentil seed can now be seen in a different light. Only the male vetch nucleus contains the DNA necessary for further development on failure of fertilization, thus supporting the suggestion of androgenesis (male parthenogenesis).

(b) If the egg nucleus in the embryo sac never contains DNA, then it is difficult to understand how an embryo can develop in apomictic forms of reproduction where the male gametic nuclei play no part. There is some evidence, however, that the egg in apomictic forms of Rubus ${ }^{10}$ does contain DNA, and this may be associated with the fact that the embryo sac has developed directly from a somatic cell.

Further work is in progress in an attempt to establish more precisely the conditions which determine, on one hand, a discontinuance of nuclear division in the haplophase and, on the other, the resumption of division in the diplophase. It forms part of an investigation being carried out with the aid of a grant from the Agricultural Research Council and under the helpful guidance of Prof. P. T. Thomas. D. G. Rowlands

Department of Agricultural Botany,

University College of Wales,

$$
\text { Aberystwyth. }
$$$$
\text { Jan. } 29
$$

1 Brachet, J., Symp. Soc. Exp. Biol., 6, 173 (1952),

"Walker, P. M. B., and Yates, Helen, Proc. Roy. Soc., B, 140, 274 (1952)

s Davidson, J. N., "The Biochemistry of the Nucleic Acids", 112 (1950).

- Painter, Bot. Gaz., 105, 58 (1943).

5 Koller, P. C., Proc. Roy. Soc. Edin., B, 51, 398 (1943).

- La Cour, L. F., Heredity, 3, 319 (1949).

'Darlington, C. D., and Thomas, P. T., Proc. Roy. Soc., B, 130, 127 (1941).

${ }^{8}$ Coulter, J. M., and Chamberlain, C. J., "Morphology of Angiosperms" (1903)

- Darlington, C. D., and Mather, K., "Elements of Genetics" (1949).

10 Crane, M. B., and Thomas, P. T., J. Genet., 40, 109 (1940).

\section{Chemical Composition of the Cell Wall of Coccidioides immitis}

THE taxonomic position of Coccidioides immitis, the causative agent of coccidioidomycosis, has been debated for some time. It is evident from the method of endosporulation exhibited both in the parasitic phase and under certain cultural conditions ${ }^{1,2}$ that the mature Coccidioides cell is a sporangium and the endospores, sporangiospores. This indicates a prob. able relationship with the Phycomycetes ${ }^{3,4}$ and even possibly with the sub-class, Zygomycetes ${ }^{5}$. However, certain characteristics inconsistent with such a rela- tionship, including the development of a richly septate mycelium and the absence of definite sporangiophores, present some taxonomic difficulties. Novertheless, as noted by Emmons ${ }^{5}$, the sporangia of many of the Zygomycetes (for example, Mortierella and Syncephalis) present so many anomalies that Coccidioides may well find a place within the group. Frey $^{6}$ has shown that the Phycomycetes may be divided into two distinct groups : the one having cellulose (Oomycetes), the other having chitin (Blastocladiales and Zygomycetes) as skeletal material of their cell walls. Therefore, we thought it might be of interest to isolate and identify the non-watersoluble polysaccharide forming the skeleton of the cell wall of $C$. immitis.

A mixture of strains 2150 and 2200 , both of which had been received originally from Dr. N. F. Conant, of Duke University Medical School, Durham, North Carolina, were grown at room temperature in shake culture in two half-litre Fernbach flasks in 1 litre of a trypsin digest of beef-heart medium containing 2 per cent glucose. The $p H$ of the medium was $7 \cdot 6$. Massive amounts of growth were obtained on this medium in 3-5 days. The cultures were killed on the fifth day by autoclaving at 10-lb. pressure for thirty minutes and the growth was harvested by filtration. The material was washed repeatedly with distilled water on a Buchner funnel to remove the adhering medium and the mycelium was then dried in an oven at $90^{\circ}-110^{\circ} \mathrm{C}$.

The dried mycelium was extracted and oxidized as described by Scholl?. Debye-Scherrer diagrams of the isolated substance were very kindly prepared for us by Dr. W. Epprecht, Eidgenössische Materialprüfungs- und Versuchsanstalt, Zürich. These showed the typical powder pattern for chitin ; there were no diffraction lines for cellulose. Nitrogen determinations confirmed these findings $(\mathrm{N}=5 \cdot 68,5 \cdot 85$ per cent).

The isolation of chitin from the mycelium of $C$. immitis is consistent with Frey's findings in the Zygomycetes. It does not allow any definite conclusion as to the taxonomic position of this organism since chitin forms the skeletal material of fungi other than the Phycomycetes. Nevertheless, it does show that all fungi pathogenic for man and animals, whether they parasitize the keratin of hairs, skin or nails or the deeper tissues, have chitin as skeletal material of their cell walls ${ }^{8,9}$.

\section{F. BLANK}

Department of Bacteriology and Immunology, McGill University, Montreal.

Ruth C. Burke*

Department of Bacteriology and Immunology and the Harvard Mycology Laboratory, Harvard Medical School, Boston, Massachusetts. Jan. 20.

* Present address : Osborn Botanical Laboratory, Yale University, New Haven, Connecticut.

${ }^{1}$ Baker, E. E., Mrak, E. M., and Smith, C. E., Farlowia, 1, 199 (1948) ${ }^{2}$ Burke, Ruth C., Proc. Soc. Exp. Biol. Med., 76, 332 (1951).

${ }^{3}$ Hartmann, M., Centr. Bakt., 1. Abt. Ref. Beiheft, 54, 253 (1912).

"Langeron, M., in "Nouveau Traité de Médecine", 4, 479 (Masson et

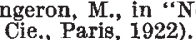

s Skinner, C. E., Emmons, C. W., and Tsuchiya, H. M., Henrici's "Molds, Yeasts and Actinomycetes", 2nd edit. (John Wiley and Sons, New York, 1947)

- Frey, R., Ber. Schweiz. Bot. Ges., 60, 199 (1950).

'Scholl, E., Monatsh., 29, 1023 (1908).

${ }^{8}$ Blank, F., Biochim. et Biophys. Acta, 10, 110 (1953).

- Blank, F., Can. J. Microbiol. (in the press). 